\title{
HYDROLOGIC CONDITIONS AT ANAKTUVUK PASS, ALASKA, 1989
}

By Harold R. Seitz

U. S. GEOLOGICAL SURVEY

Open-File Report 90-591

Prepared in cooperation with the

NORTH SLOPE BOROUGH

Anchorage, Alaska

1991 


\section{U.S. DEPARTMENT OF THE INTERIOR}

MANUEL LUJAN, JR., Secretary

\section{U.S. GEOLOGICAL SURVEY}

Dallas L. Peck, Director

For additional information write to:

\section{District Chief}

U.S. Geological Survey

4230 University Drive, Suite 201

Anchorage, Alaska 99508-4664
Copies of this report can be purchased from:

U.S. Geological Survey

Books and Open-File Reports Section

Federal Center, Bldg. 810

Box 25425

Denver, Colorado 80225 


\section{CONTENTS}

Page

Abstract ......................... 1

Introduction . ...................... 1

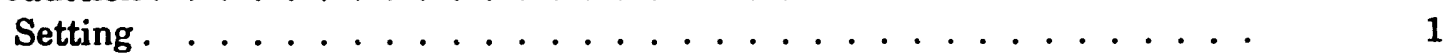

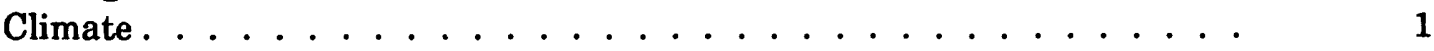

Sources of water . . . . . . . . . . . . . . . . . . . . . . . 4

Water quality ......................... 4

Additional water supply . . . . . . . . . . . . . . . . . . . . . . . . . . . 13

References cited . . . . . . . . . . . . . . . . . . 13

\section{ILLUSTRATIONS}

Figure $\quad$ 1. Map showing location of the Anaktuvuk Pass area .. . . . . . 2

2. Graphs showing temperature and precipitation data for the Anaktuvuk Pass area.. . . . . . . . . . . . . 3

3. Aerial photograph of Anaktuvuk Pass .. . . . . . . . . . 5

4-6. Diagrams showing logs of:

4. Central supply well at Anaktuvuk Pass . . . . . . . . . . . . 6

5. Destroyed well in bed of Contact Creek at Anaktuvuk Pass. . . 7

6. School well at Anaktuvuk Pass . . . . . . . . . . . . . 8

\section{TABLES}

Table 1. Analysis of water from Eleanor Lake . . . . . . . . . . . . . . 9

2. Analysis of water from Contact Creek. . . . . . . . . . . . . . . 10

3. Analysis of water from the central supply well. . . . . . . . . . . . 11

4. Analysis of water from the school well. . . . . . . . . . . . . . . 12 


\section{CONVERSION FACTORS AND ABBREVIATIONS}

Multiply inch-pound unit

inch (in.)

foot $(\mathrm{ft})$

mile (mi)

acre

gallon per minute (gal/min)

gallon per day (gal/d)

degree Fahrenheit $\left({ }^{\circ} \mathbf{F}\right)$
By

25.4

0.3048

1.609

0.4047

0.06308

0.003785

${ }^{\circ} \mathrm{C}=5 / 9 \times\left({ }^{\circ} \mathrm{F}-32\right)$
To obtain metric unit

millimeter (mm)

meter (m)

kilometer (km)

hectare

liter per second $(\mathrm{L} / \mathrm{s})$

cubic meter per day $\left(\mathrm{m}^{3} / \mathrm{d}\right)$

degree Celsius $\left({ }^{\circ} \mathrm{C}\right)$

Other abbreviations in this report are:

$\mathrm{mg} / \mathrm{L}, \quad$ milligram per liter

$\mu \mathrm{g} / \mathrm{L}, \quad$ microgram per liter

$\mu \mathrm{S} / \mathrm{cm}$, microsiemen per centimeter at 25 degrees Celsius 


\title{
HYDROLOGIC CONDITIONS AT ANAKTUVUK PASS, ALASKA, 1989
}

\author{
by Harold R. Seitz
}

\begin{abstract}
Hydrologic conditions at the village of Anaktuvuk Pass in the central Brooks Range of Alaska were reviewed in September 1989. The work was done to provide data that would assist the village in the location and development of additional water supplies needed to support a piped sewagehandling system. Well logs and water-quality data from existing wells indicated that the aquifer in the area north of the central supply well and adjacent to the west bank of Contact Creek would sustain a well capable of producing the needed volume of good-quality water.
\end{abstract}

\section{INTRODUCTION}

Anaktuvuk Pass is a Nunamiut (Eskimo) village in the central Brooks Range (fig.1). Its population has grown from 66 people in 1950 to about 250 in 1990 . The installation of a pumpedsewage system has been proposed for the village, and additional water supplies are needed to support such a system. In order to provide the data needed to assist in locating and developing additional water supplies, the U.S. Geological Survey, in cooperation with the North Slope Borough, visited the village to examine hydrologic conditions in September 1989. This report is a summary of the information collected during the visit and a review of work of earlier investigators at Anaktuvuk Pass.

The consulting engineer for the North Slope Borough provided background information and conveyed water needs. Personnel from the Anaktuvuk Pass Municipal Services provided local information and transportation, and acted as guides during the Survey's visit to the village.

\section{Setting}

The village of Anaktuvuk Pass is at $2,200 \mathrm{ft}$ altitude in a U-shaped glaciated mountain valley that forms the divide between two major watersheds, the Anaktuvuk and John Rivers. The valley floor is a relatively flat alluvial plain between the Soakpak and Three River Mountains. The drainage of the village site is through Contact Creek to John River, which flows southward from the pass. Eleanor Lake is about $0.5 \mathrm{mi}$ northeast of the village and has a surface area of about 30 acres. It drains into the headwaters of the Anaktuvuk River, which flows to the north.

\section{Climate}

Continental arctic weather dominates the climate of the area. Average minimum temperatures remain below freezing for most of the year (fig. 2). December is the coldest month with an average temperature of minus $14.3^{\circ} \mathrm{F}$; July is the warmest month with an average temperature of $50.5^{\circ} \mathrm{F}$ (Arctic Environmental Information and Data Center, 1986). Precipitation averages 10.65 in/yr; half occurs as rain showers from June through September and half as snow from October through May (fig. 2). 


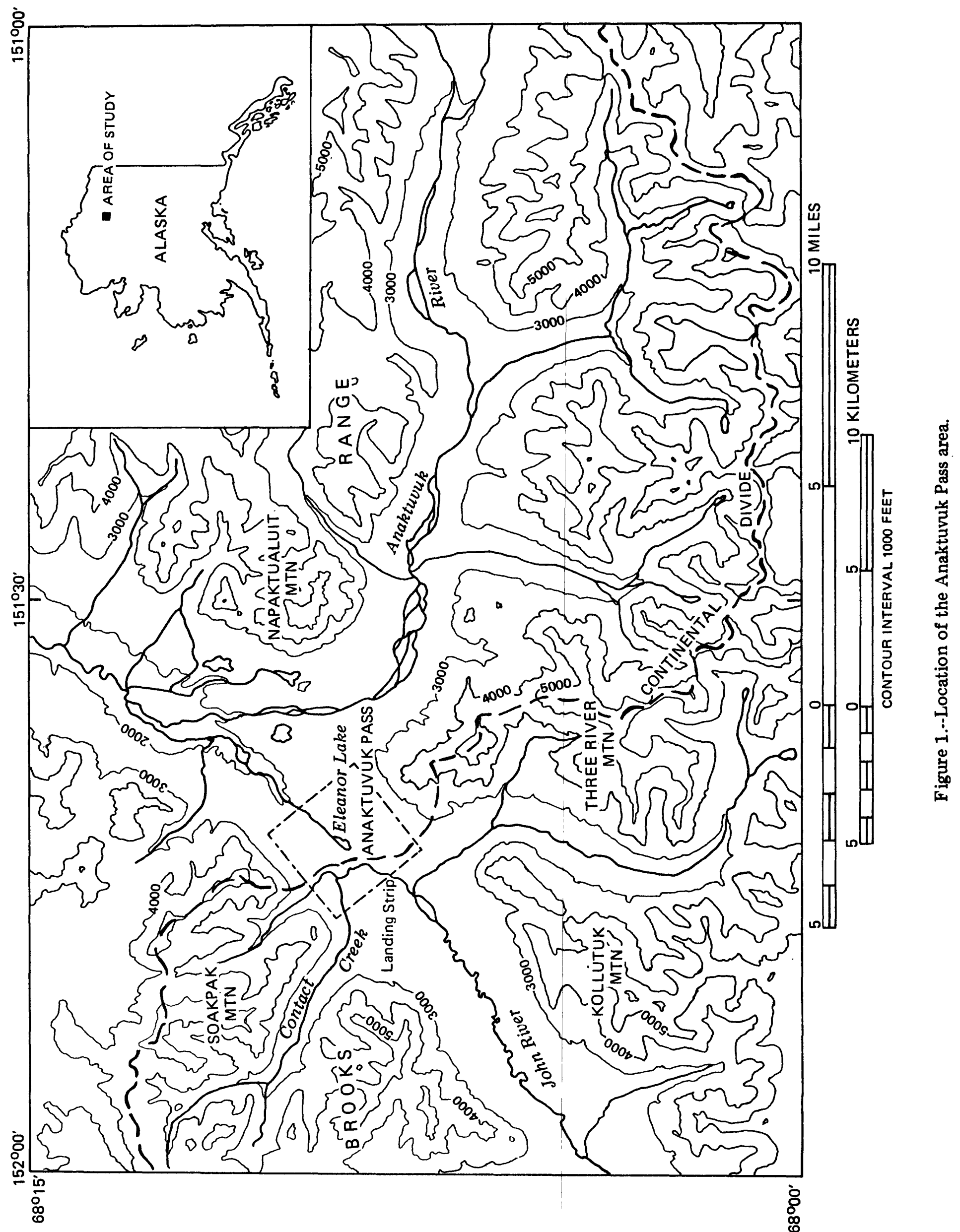




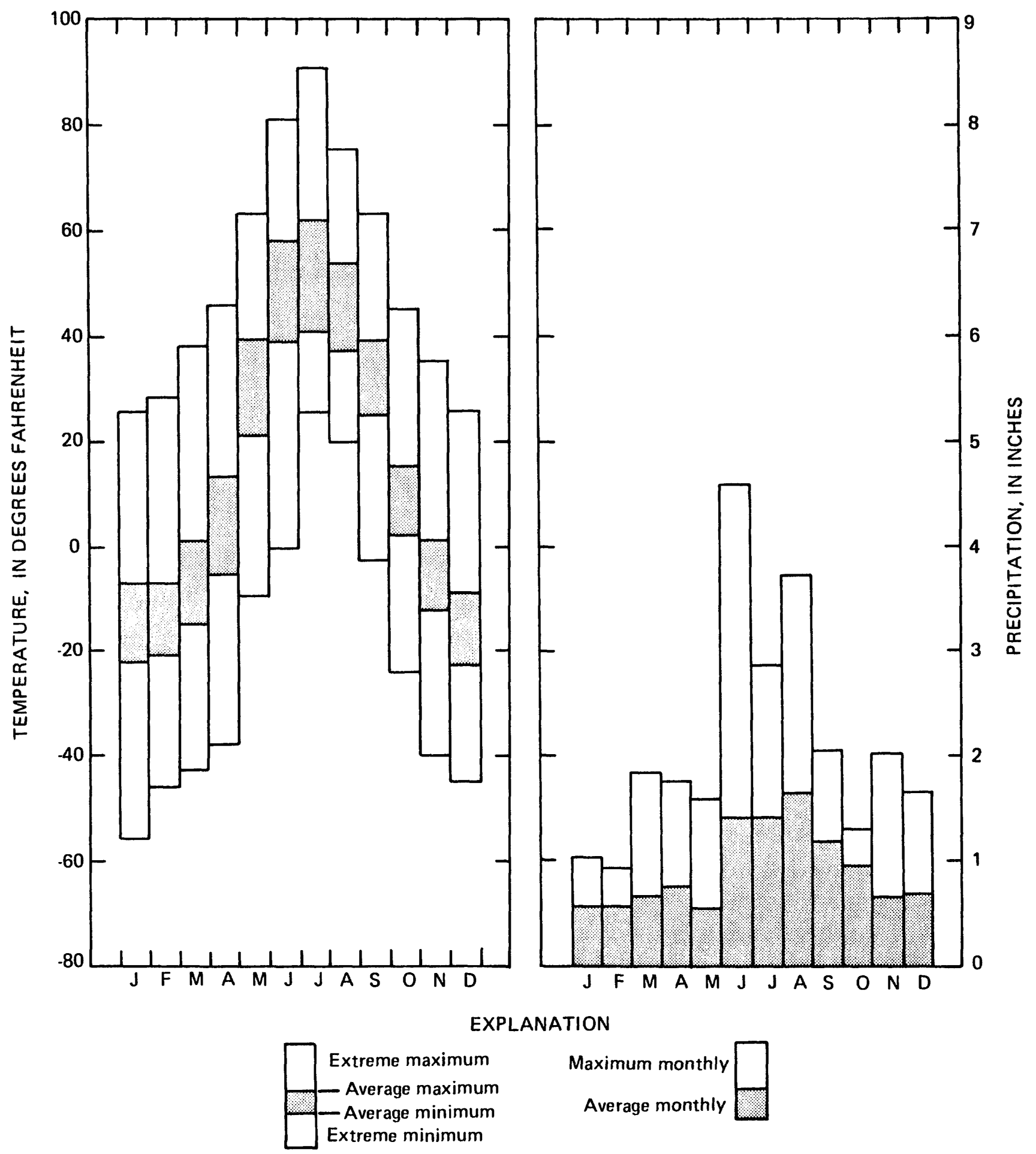

Figure 2.--Temperature and precipitation data for the Anaktuvuk Pass area. (Data from University of Alaska, 1978.) 


\section{SOURCES OF WATER}

Surface-water sources at Anaktuvuk Pass are Contact Creek (which flows through the village in a southerly direction) and Eleanor Lake (fig. 3), as well as springs near the southwest end of the airstrip. During the winter months, Contact Creek ceases to flow as icings occur and Eleanor Lake freezes over. On September 21, 1989, soundings of Eleanor Lake were made along a north-south meander line using a lead line; the maximum depth of the lake was found to be $42 \mathrm{ft}$ deep on that date. All surface water in the vicinity of Anaktuvuk Pass (including the springs) has been reported to be contaminated by bacteria (Sloan, 1972); thus, surface water is not readily usable as a source of drinking water without treatment.

In 1972, the Geological Survey made a water-resources reconnaissance of the area (Sloan, 1972); in 1974, two wells were drilled to develop ground water as the drinking-water source for the village. One well (No. UD01500218DAAA1) was drilled to a depth of $72 \mathrm{ft}$ (fig. 4) and now serves as the central water supply for the village. The water is distributed to individual houses, businesses, and shops by tank truck. The second well (No. UD01500217BCCC1) was drilled in the bed of Contact Creek to a depth of $71 \mathrm{ft}$ (fig. 5). This well was destroyed when Contact Creek was channelized to prevent spring flooding. A third well (No. UD01500218DADC1), drilled in 1978 to a depth of $92 \mathrm{ft}$ (fig. 6), serves as the water supply for the village school. See figure 3 for the locations of the wells.

\section{WATER QUALITY}

In September 1989, water samples were collected from the middle of Eleanor Lake, from Contact Creek at the north end of the village, and from the well head of the central supply well. The samples were analyzed for common ions, nutrients, selected trace metals, and the presence of fecal bacteria. Water from the central supply well had previously been sampled for analysis by the Geological Survey on May 2, 1974.

Analyses of water samples from Eleanor Lake (table 1) and Contact Creek (table 2) indicated that the inorganic chemical quality of the water meets the criteria for drinking water established by the U.S. Environmental Protection Agency (1977). This water would be suitable for drinking, except for the presence of fecal bacteria. This contamination is probably from animals and waterfowl.

Analyses of water samples from the central supply well made in May 1974 and September 1989 (table 3) indicated that the water is of acceptable quality for drinking-water use. The water contains low levels of the following: dissolved solids $(89 \mathrm{mg} / \mathrm{L})$, hardness $\left(96 \mathrm{mg} / \mathrm{L}\right.$ as $\left.\mathrm{CaCO}_{3}\right)$, nutrients ( $<0.010 \mathrm{mg} / \mathrm{L}$ of nitrogen; $<0.010 \mathrm{mg} / \mathrm{L}$ of phosphorus), and trace metals. The water meets drinking water standards established by the Alaska Department of Environmental Conservation (1982) for all components except mercury.

The sample collected on September 21,1989 , contained $4.0 \mu \mathrm{g} / \mathrm{L}$ of mercury, which exceeds the Alaska drinking water criterion. The sample collected in 1974, however, contained no detectable mercury. Regular sampling for the State of Alaska's Village Safe Water Office, including a September 1989 sample, shows no mercury contamination (Jane Dale, Alaska Village Safe Water Office, oral commun., 1990). It appears that the Geological Survey's September sample was contaminated during collection, handling, or laboratory analysis. The most likely source of the contamination is mercuric chloride used to preserve nutrient samples. 


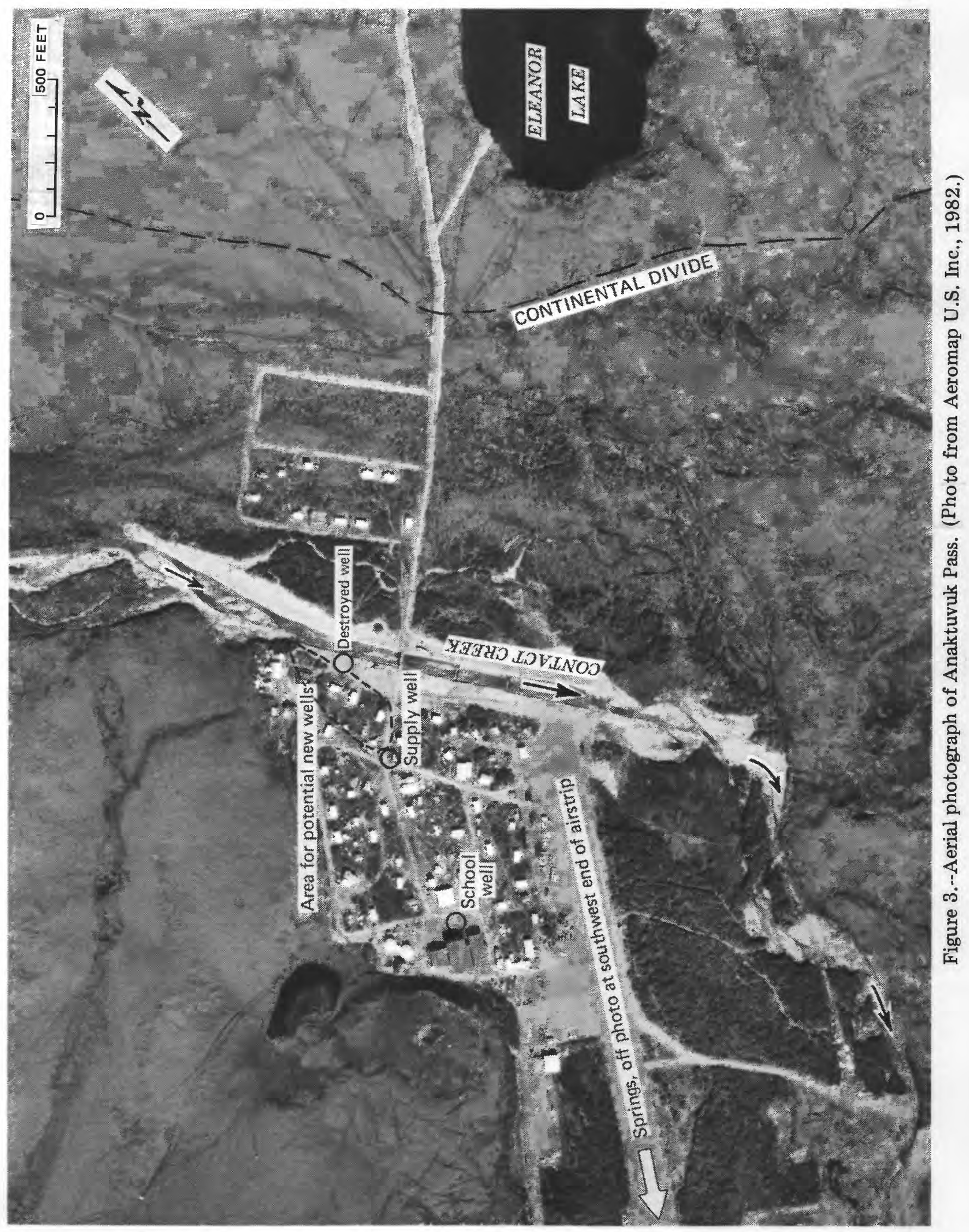


WELL NO. UD01500218DAAA1

DATE STARTED

4-25-74

COMPLETED 4-29-74 DRILLER

Grinder-Estabrook

TOTAL DEPTH OF WELL FT. CASING INSTALLED

68' DIAMETER 6"

GROUT SCREEN SIZE _ 30 slot LENGTH $5^{\prime}$ STATIC WATER LEVEL FT.

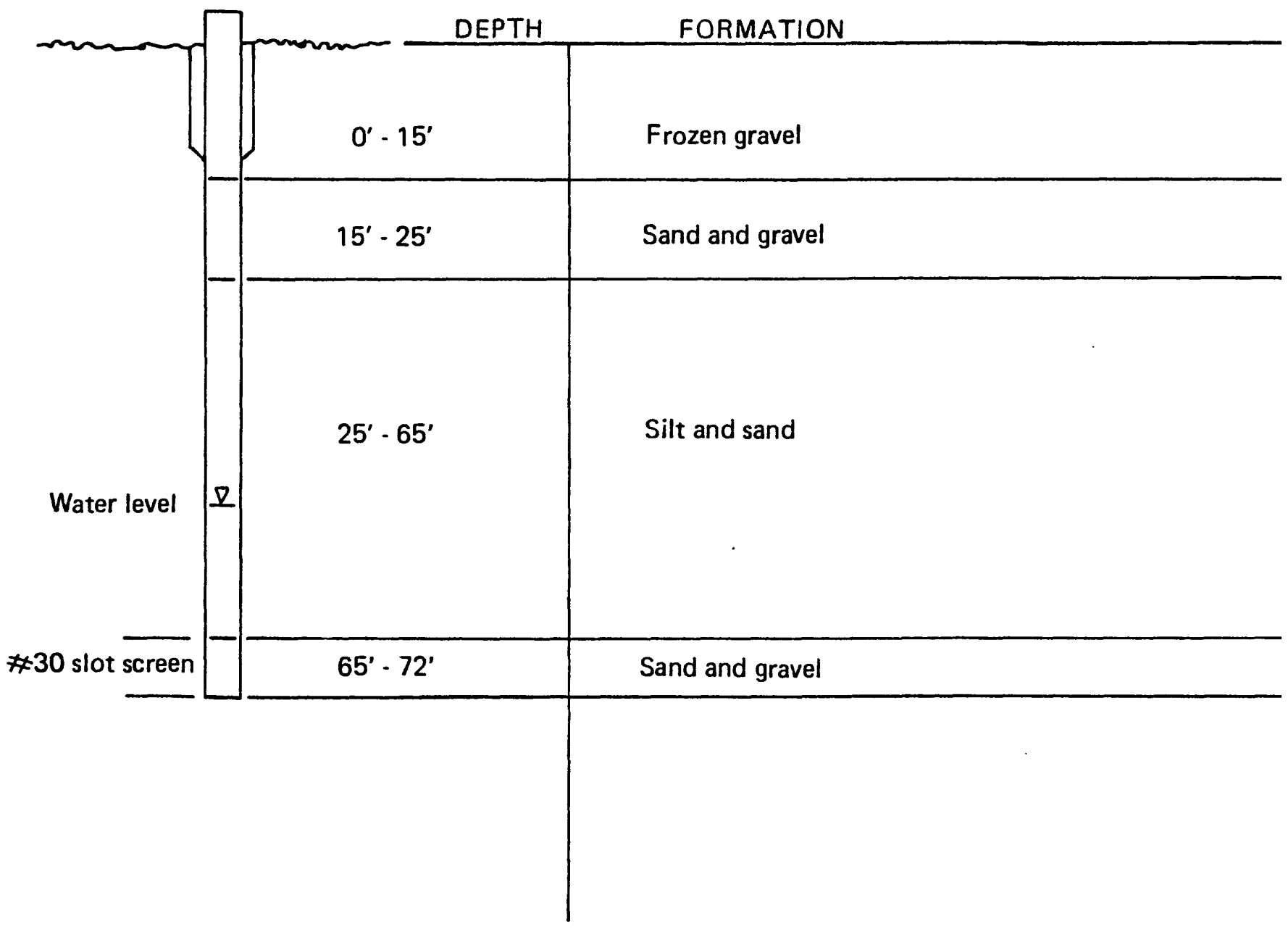

Figure 4.--Log of central supply well at Anaktuvuk Pass.(Log from U.S. Public Health Service.) 
WELL NO. UD01500217BCCC1

DATE STARTED

4.9-74

COMPLETED 4-17-74 DRILLER

Grinder

TOTAL DEPTH OF WELL FT.

CASING INSTALLED $71^{\prime}$ DIAMETER

6" GROUT None SCREEN SIZE None LENGTH

STATIC WATER LEVEL $14^{\prime}$ HRS. PUMPED 32 GAL/MIN 30 DRAWDOWN FT.

\begin{tabular}{|c|c} 
Water level & FORMATION \\
\hline $10^{\prime}-30^{\prime}$ & Sand and gravel \\
\hline $30^{\prime}-50^{\prime}$ & $\begin{array}{l}\text { Sand and gravel } \\
\text { Small amount of water at } 30 \text { feet }\end{array}$ \\
\hline $50^{\prime}-65^{\prime}$ & Sand and gravel \\
\hline $65^{\prime}-71^{\prime}$ & Sand and gravel \\
\hline & Sand and gravel \\
\hline
\end{tabular}

Figure 5.--Log of destroyed well in bed of Contact Creek at Anaktuvuk Pass . (Log from U.S. Public Health Service.) 
WELL NO. UD01500218DADC1

DATE STARTED 4-18-78

COMPLETED 4-26-78 DRILLER Swan and Ice Drilling

TOTAL DEPTH OF WELL 92 FT. CASING INSTALLED 80 DIAMETER $6^{\prime \prime}$ GROUT $30^{\prime}$

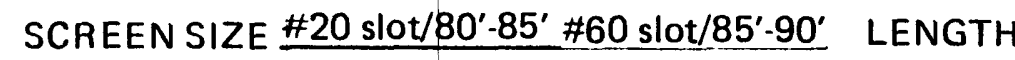
$5^{\prime} / 5^{\prime}$

STATIC WATER LEVEL HRS. PUMPED 14 GAL/MIN 42 DRAWDOWN 8 FT.

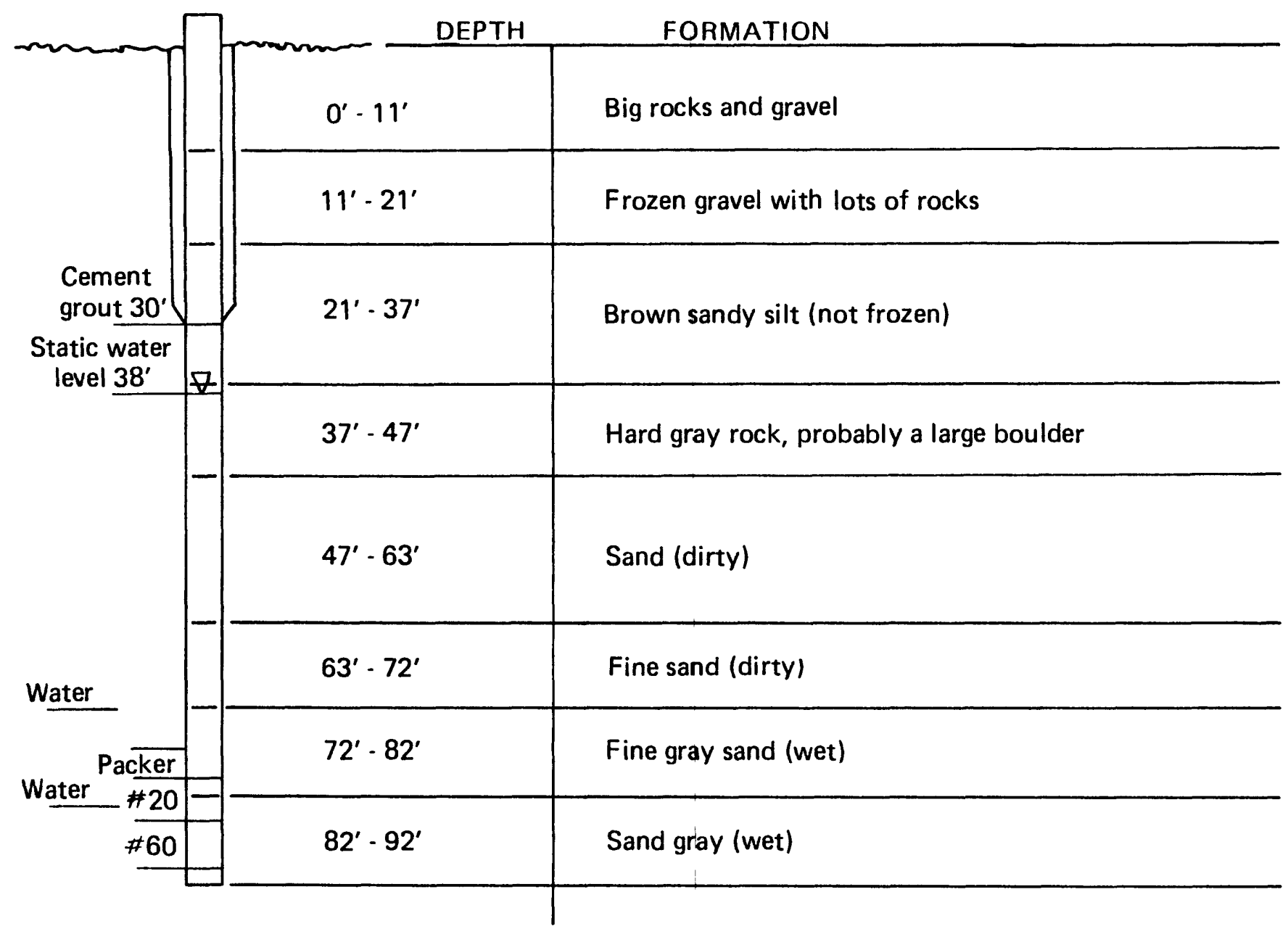

Figure 6.--Log of school well at Anaktuvuk Pass (Log from Dowl Engineers, 1978.) 
[HS/cm, microsiemens per centimeter at $25^{\circ} \mathrm{C} ;{ }^{\circ} \mathrm{C}$, degree Celsius; NTU, nephelometric turbidity units; cols./100 mL, colonies per $100 \mathrm{milliliters;} \mathrm{mg/L,} \mathrm{milligrams} \mathrm{per} \mathrm{liter;} \mathrm{\mu g/L,} \mathrm{micrograms} \mathrm{per} \mathrm{liter]}$

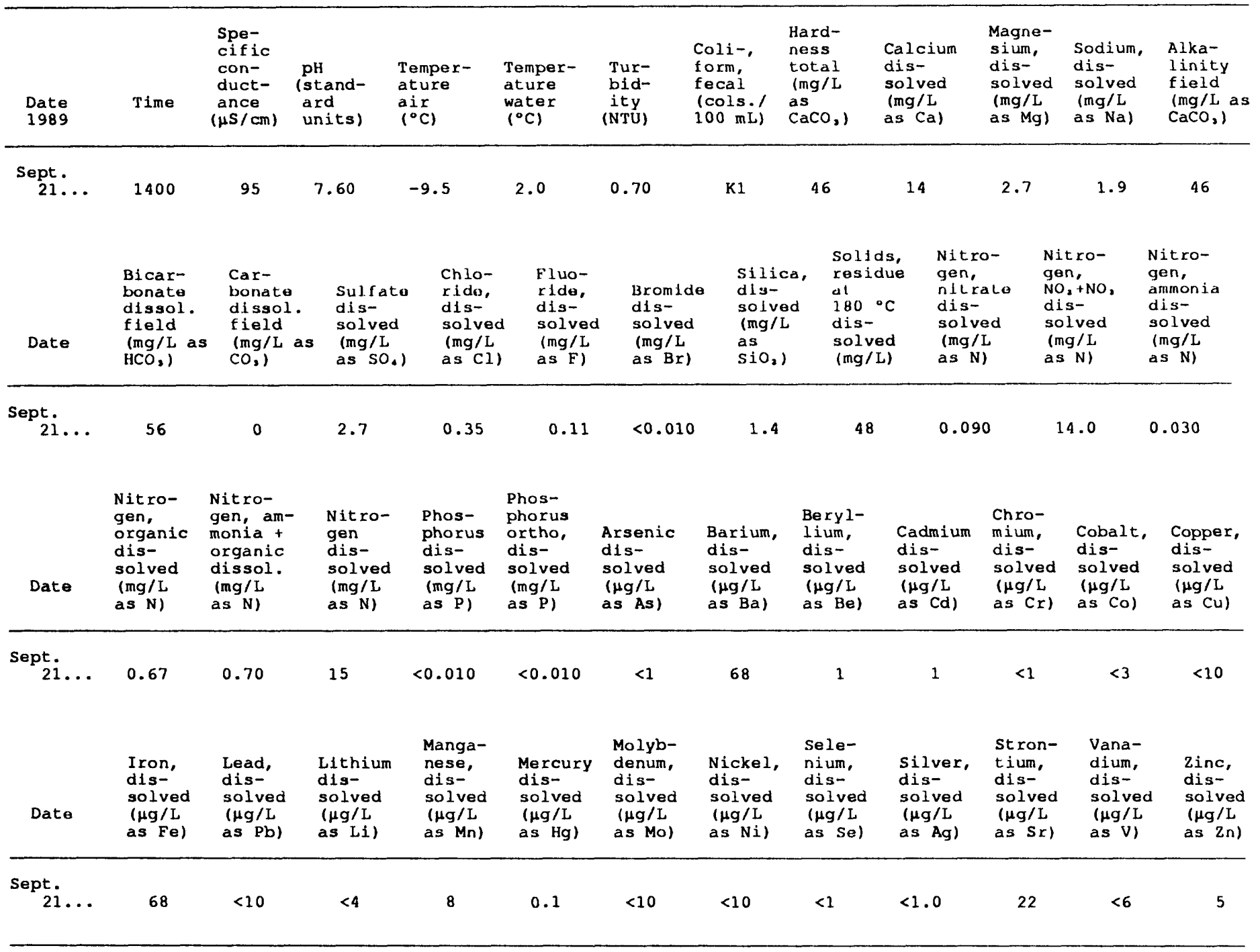

K Non-ideal colony count 
[ft $\% / \mathrm{s}$, cubic feet per second; $\mu \mathrm{S} / \mathrm{cm}$, microsiemens per dentimeter at $25{ }^{\circ} \mathrm{C}$; ${ }^{\circ} \mathrm{C}$, degree Celsius; NTU, nephelometric turbidity units; cols./100 mL, colonies per 100 milliliters; $\mathrm{mg} / \mathrm{L}, \mathrm{milligrams}$ per 11ter; $\mu \mathrm{g} / \mathrm{L}$, micrograms per liter]

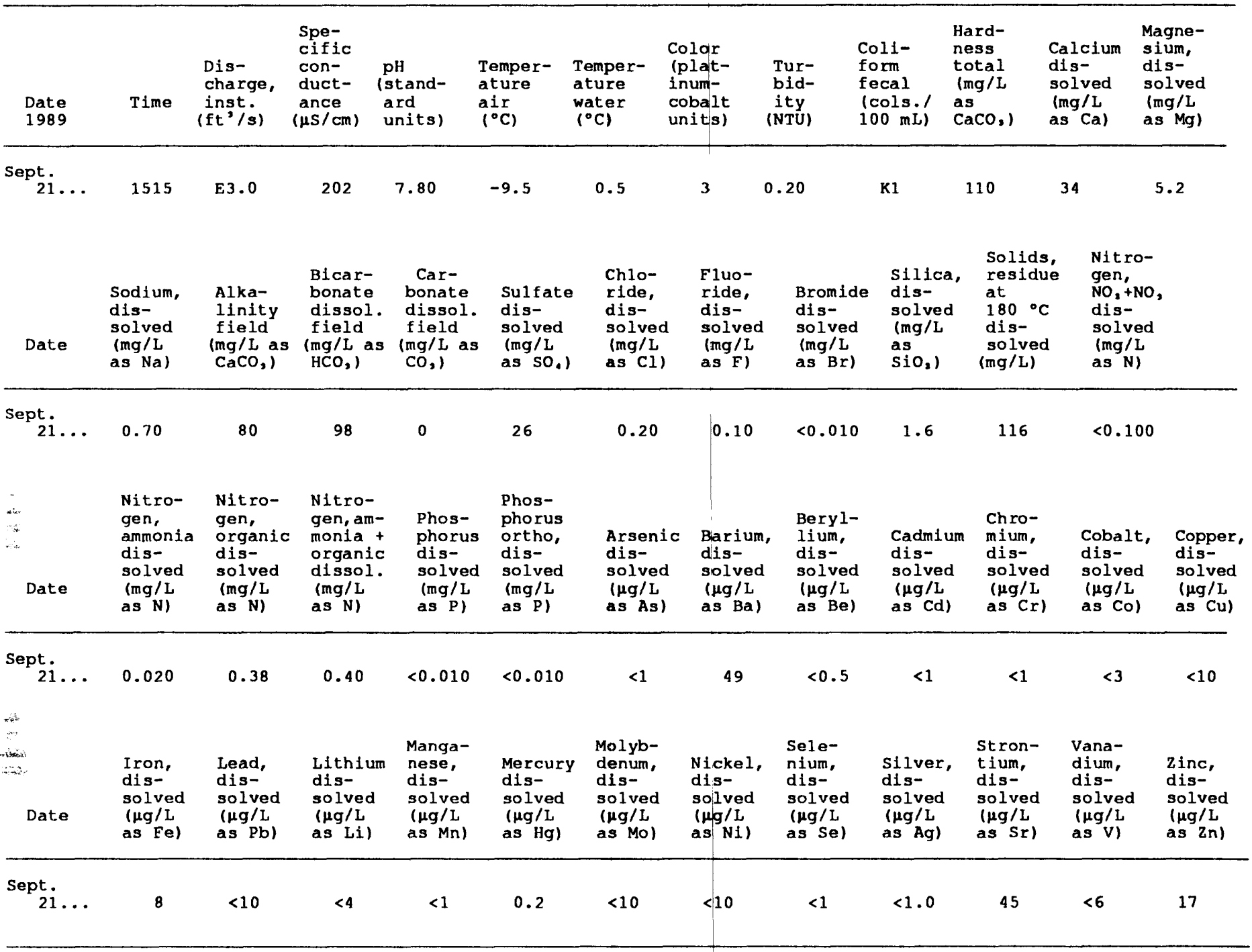

$K$ Non-ideal colony count 
[ $\mu \mathrm{S} / \mathrm{cm}$, microsiemens per centimeter at $25^{\circ} \mathrm{C}$; ${ }^{\circ} \mathrm{C}$, degree Celsius; NTU, nephelometric turbidity units; mg/L, milligrams per liter; $\mu g / L$, micrograms per liter]

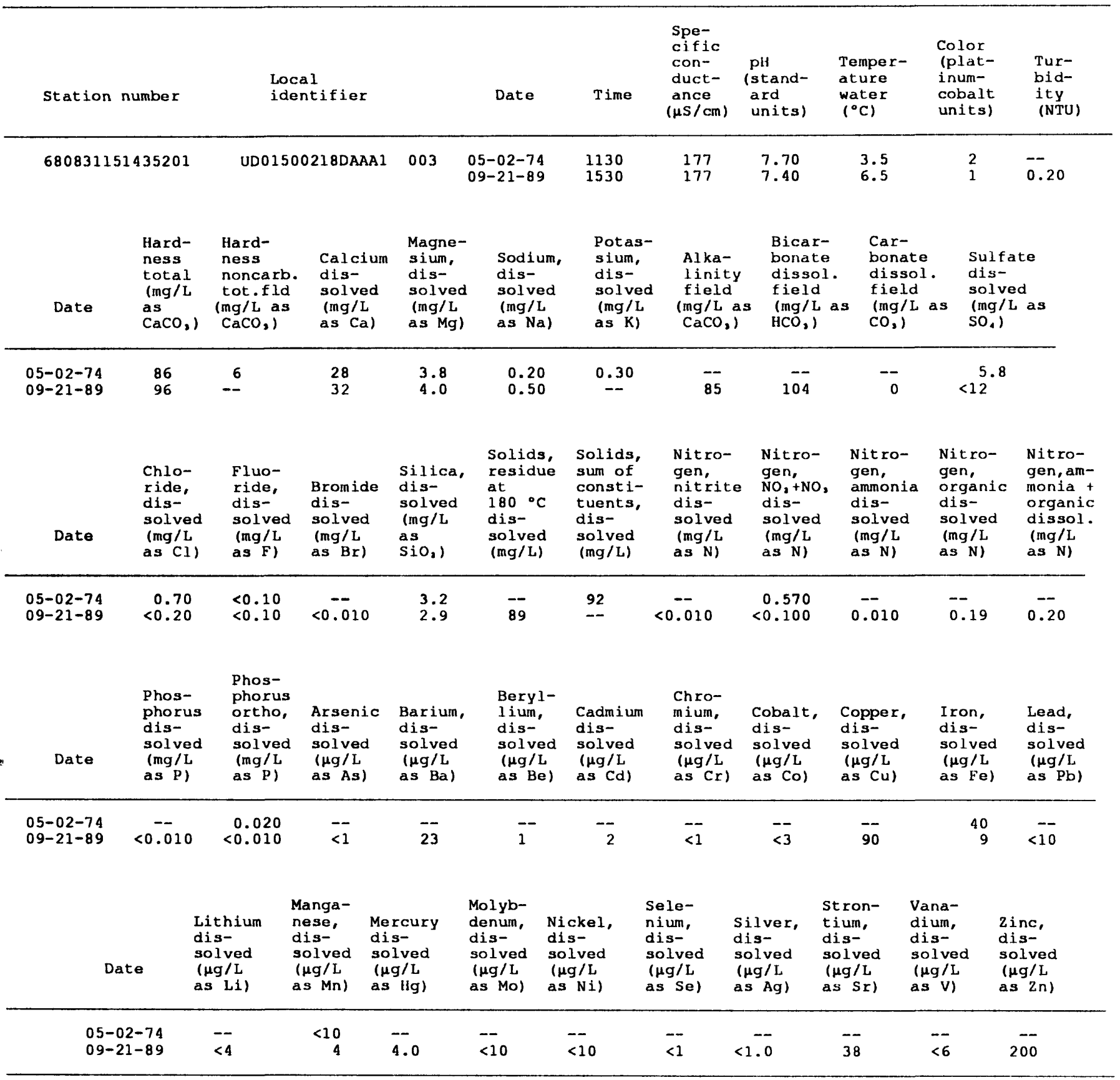


Table 4.- Analysis of water from the school well

(No. UD01500218DADC1)

[Analysis reported by DOWL Engineers (1978);

all values in milligrams per liter]

\begin{tabular}{lccccc}
\hline Date & Calcium & $\begin{array}{c}\text { Iron, } \\
\text { total }\end{array}$ & Magnesium & Manganese $\begin{array}{c}\text { Hardness } \\
\text { as CaCO }\end{array}$ \\
\hline $6-16-78$ & 117 & 1.1 & 54 & 0.77 & 517 \\
$7-24-78$ & 159 & 0.7 & 62 & 1.1 & 652 \\
\hline
\end{tabular}


Water from the school well was sampled on June 16 and July 24, 1978 (DOWL Engineers, 1978). The analyses of these samples (table 4) indicated that the water was very hard ( $>500 \mathrm{mg} / \mathrm{L}$ as $\mathrm{CaCO}_{3}$ ), and contained elevated levels of calcium, iron, magnesium, and manganese. On the basis of these analyses, the water is considered potable, but would cause staining of fixtures. It would be difficult to use for wash water, as the hardness would limit the sudsing of soap. Trace metals were not reported.

\section{ADDITIONAL WATER SUPPLY}

Historically, whenever a piped-sewage system is installed in an area, water usage rises dramatically. For Anaktuvuk Pass, it is estimated that a water supply of $15,000 \mathrm{gal} / \mathrm{d}$ will be needed to support a new sewage system. A well (or wells) that produces 100 to $300 \mathrm{gal} / \mathrm{min}$ would provide an adequate supply. A review of existing well logs and water-quality data from the central supply and school wells indicated that the aquifer that underlies the area north of the central supply well and adjacent to the west bank of Contact Creek (area shown on figure 3) would sustain a well (or wells) capable of producing the needed volume of good-quality water. A drilled well (or wells) 8 in. or larger in diameter, drilled to a depth of 70 to $80 \mathrm{ft}$ and completed in gravel, probably would provide such a yield.

\section{REFERENCES CITED}

Alaska Department of Environmental Conservation, 1982, Drinking water regulations: 20 p.

Arctic Environmental Information and Data Center, 1986, Alaska climate summaries: Alaska Climate Center Technical Note Number 3, unpaged.

DOWL Engineers, 1978, As-built report--water well for Anaktuvuk Pass School: Anchorage, Alaska, DOWL Engineers report, $10 \mathrm{p}$.

Sloan, C.E., 1972, Water-resources reconnaissance of Anaktuvuk Pass: U.S. Geological Survey openfile report, $12 \mathrm{p}$.

University of Alaska, 1978, Community map, Anaktuvuk Pass: University of Alaska, Fairbanks, 1 sheet.

U.S. Environmental Protection Agency, 1977, Quality criteria for water, 1976: U.S. Government Printing Office, 256 p. 